\title{
New Recent foraminiferal genera and species from the lagoon at Madang, Papua New Guinea
}

\author{
MARTIN R. LANGER \\ Museum of Paleontology \\ University of California \\ Berkley, CA. 94720, U.S.A.
}

\begin{abstract}
Two new genera and eight new species of benthic foraminifera are described from the shallow water, tropical lagoon of Madang, Papua New Guinea. The new hauerinid genus Pseudolachlanella is characterized by juvenile cryptoquinqueloculine, adult almost massiline arranged chambers, and a slitlike, curved aperture with parallel sides and a long, slender, curved miliolid tooth. Pitella haigi n. gen., n. sp. is a new foraminifera with cryptoquinqueloculine arranged chambers, an almost entirely pitted shell surface (pseudopores) and a rounded aperture with a short simple tooth. Among the other species described as new are four hauerinids and two agglutinated foraminifera All new species described here occur sporadically in the shallow water back- and forereef environments of the lagoon $(0-55 \mathrm{~m})$, and live infaunally and epifaunally in well-oxygenated, fine and coarse grained biogenic sediments. They are absent in muddy, organic-rich, low-oxygen sedimentary environments within bay inlets where variations of salinity are
\end{abstract} considerable. J. Micropalaeontol. 11 (1): 85-93, June 1992.

\section{INTRODUCTION}

The diverse, tropical foraminiferal faunal community from Papua New Guinea (PNG) represents an important link between the Red Sea - East-African faunal province (Hottinger, 1983, Reiss and Hottinger, 1984, Hottinger and Pecheux (in press) and the biogeographic province of the Great Barrier Reef. Despite a very recent inventory of genera (Loeblich \& Tappan, 1987) and a large number of foraminiferal studies carried out in this region (Brady, 1884; Millett, 1898a, b, c; Heron-Allen \& Earland, 1915; Cushman, 1921, 1932, 1933, 1942; Said, 1949; Collins, 1958; Graham \& Militante 1959; Hofker, 1927, 1930, 1933, 1951, 1968; Rasheed 1971; Margerel, 1981; Baccaert, 1987; Debenay, 1986, 1988; Haig, 1988), the systematic status of numerous genera and species is still insufficient (for review see e.g. Haynes, 1990) and open nomenclature has often been used (e.g. Hottinger et al., in press). By studying the distribution patterns of shallow water benthic foraminiferal assemblages from the lagoon at Madang (PNG), 182 species were recorded (Langer \& Lipps in prep.). Eight of them are described here as new. Morphological properties of two of the miliolids do not correspond to those of any previously known genera and the new genera Pseudolachlanella and Pitella are described.

\section{MATERIAL AND METHODS}

The present-day barrier, fringing and patch reefs of the lagoon at Madang, represent the largest reef system along the north coast of Papua New Guinea. The barrier reef parallels the $\mathrm{N}-$ $S$ trending lagoon, is broken by three major passes, and extends over $17 \mathrm{~km}$ from the Schering Peninsula in the $S$ to the Ottilien Pass in the N (Fig. 1). The lagoon is 1 to $4 \mathrm{~km}$ wide and 10 to $52 \mathrm{~m}$ deep. The central lagoon floor is covered by biogenic rubble, sand and calcareous silt. The reef crest is characterized by digitate, robust Acropora corals; the unconsolidated coral

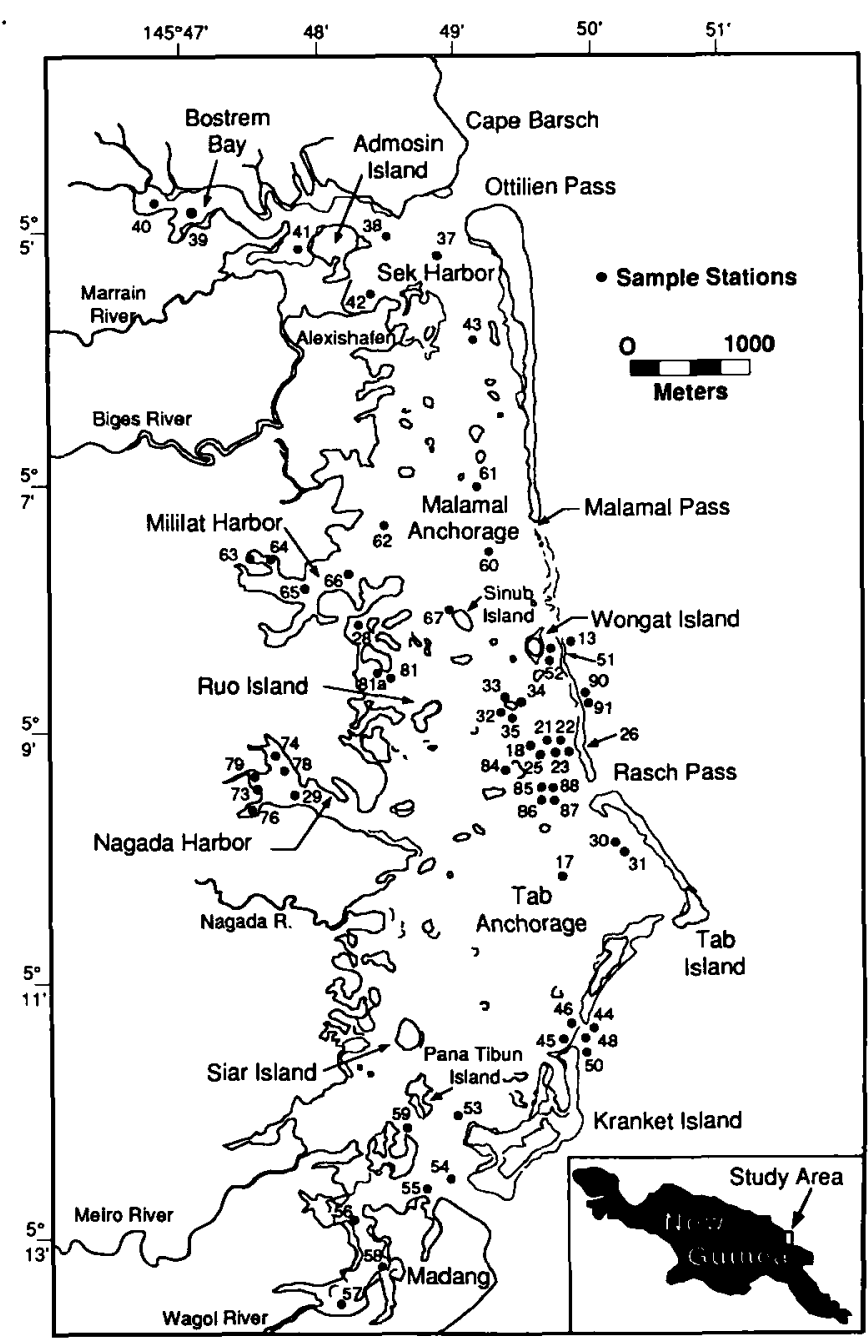

Fig. 1. Sampling sites in the lagoon at Madang, Papua New Guinea. 
rubble floor has intervening sand channels and lacks extensive algal ridges.

The four major inlet systems along the west coast of the lagoon (Madang, Nagada, Mililat Harbours and Bostrem Bay), are strongly influenced by the inflow of fresh water from rivers. The inlet bottoms are covered by a dark, organic-rich mud containing locally abundant scaphopods and a highly specialized foraminiferal fauna (Ammonia convexa, Spiroloculina attenuata, Parrellina hispidula and Elphidium sp. 1).

Fifty-seven samples covering major parts of the lagoon, the bay inlets and the forereef were collected in summer 1989 at depths ranging from $1-52 \mathrm{~m}$ (Fig. 1). The samples were collected by J.H. Lipps using SCUBA or a small rectangular pipe dredge. All sediment samples were washed over $63 \mu \mathrm{m}$ mesh sieves. Between $50-450$ specimens were picked out of each sample or sample split, identified to species level and counted. One hundred and eighty-two species were identified and photographed using SEM. The microhabitat distribution pattern of the foraminiferal faunal assemblages within the lagoon and a catalogue of the species identified will be published at a later date (Langer \& Lipps, in prep.). In the following taxonomic note, a morphological description is given for the new genera and species. The taxonomy adopted here follows the classification of Loeblich \& Tappan (1987). Holotypes and paratypes are deposited at the Museum of Paleontology, University of California, Berkeley (UCPM).

\section{SYSTEMATIC TAXONOMY}

Order Foraminiferida Eichwald, 1830

Suborder Textulariina Délage \& Hérouard, 1896

Superfamily Spiroplectamminacea Cushman, 1927

Family Spiroplectamminidae Cushman, 1927

Genus Spiroplectinella Kisel'man, 1972

Spiroplectinella hottingeri sp. nov.

(Pl. 1, figs 1-3)

Derivation of name. This species is named in honour of Prof. Lukas Hottinger (University of Basel, Switzerland) for his fundamental work in the Red Sea - East African faunal province.

Diagnosis. A small, heart-shaped species of Spiroplectinella with planispirally arranged initial chambers and biserially arranged adult chambers.

Holotype. Pl. 1, figs 1-2. Reference UCMP No.39671.

Paratypes. Pl. 1, fig. 3. Reference UCMP No. 39672.

Material. The holotype and two paratypes.

Locality. The holotype is from sample No. L25, Lagoon of Madang, N of Rasch Pass; $14 \mathrm{~m}$, Papua New Guinea. The paratypes are from sample No. L34, Lagoon of Madang, S-W of Wongat Island; $24.3 \mathrm{~m}$, Papua New Guinea.

Description. Test free, heart- to fan-shaped in lateral view, broader than high in the adult stage, laterally compressed with subacute periphery. Initial chambers planispirally arranged and somewhat thickened (3-4 chambers), later chambers biserially arranged (15-17 chambers). Chambers rapidly increase in width as added. Sutures are curved and slightly depressed. Wall agglutinated by heterogenous material. The peripheral wall is penetrated by straight and branching parapores (sensu Hottingeretal.,1990). The aperture is a basal slit at the inner margin of the final chamber.

Dimensions. Maximum test height of the holotype $0.57 \mathrm{~mm}$. Occurrence. Spiroplectinella hottingeri is irregularly distributed in medium grained, backreef sediments (biogenic) in the lagoon of Madang, rare in the forereef area.

Remarks. As has been shown by Bender (1989) and Cimerman \& Langer (1991) the type species Spiroplectinella wrightii is both initially planispiral and perforated by minute parapores. Spirorutilus became a junior synonym of Spiroplectinella (compare Hottinger et al., 1990a and Bender, 1989). Therefore the species described here must be placed in Spiroplectinella Kisel'man.

Superfamily Textulariacea Ehrenberg, 1838

Family Textulariidae Ehrenberg, 1838

Subfamily Textulariinae Ehrenberg, 1838

Genus Sahulia Loeblich \& Tappan, 1985

Sahulia lutzei sp. nov.

(Pl. 1, figs 4-6)

Derivation of name. This species is named in honour of Prof. Gerhard Lutze (University of Kiel, Germany) for his work on benthic foraminifera in surface sediments of the Persian Gulf. Diagnosis. A subtriangular, coarsely agglutinated species with biserially arranged chambers provided with an aperture at the inner margin of the final chamber with a short flaplike lip bordered at its end by apertural reentrants.

Holotype. Pl. 1, fig. 5. Reference UCMP No. 39673. Paratype. Pl. 1, figs 4, 6. Reference UCMP No.396734.

Material. The holotype and eight paratypes.

Locality. The holotype is from sample No. L22, Lagoon of Madang, N of Rasch Pass; 24.3m, Papua New Guinea. The paratype is from sample No. L23, Lagoon of Madang, $\mathrm{N}$ of Rasch Pass; $20.8 \mathrm{~m}$, Papua New Guinea.

Description. Test free, subtriangular to wedge-shaped in lateral view, broader than high in the adult stage, laterally compressed with subacute periphery. Initial part somewhat thickened. Chambers are biserially arranged throughout and rapidly increase in width as added. In adult specimens the number of chambers is between 18 and 24 . Sutures are slightly curved and somewhat depressed. Peripheral walls are coarsely agglutinated by heterogenous material. Apertural face more smoothly finished. The peripheral wall is penetrated by straight

\section{Explanation of Plate 1}

Figs 1-3. Spiroplectinella hottingeri, sp. nov. (L25). Fig. 1, apertural view, (holotype) x55; Fig. 2, side view (holotype) x60; Fig. 3, straight and branching parapores in broken peripheral wall, (paratype) $\times 850$.

Figs 4-6. Sahulia lutzei sp. nov. (L22). Fig. 4, apertural view, (paratype) x80; Fig. 5, side view, (holotype) x60; Fig. 6, basal view, (paratype) x60. Figs 7-11.Cycloforina collinsi sp. nov. (L52). Fig. 7, apertural view, (paratype) x80: Fig. 8, apertural view, (paratype) x115; Fig. 9, side view, (paratype) x55; Fig. 10, apertural view, (holotype) x55; Fig. 11, enlargement of the apertural region, (holotype) x800. 


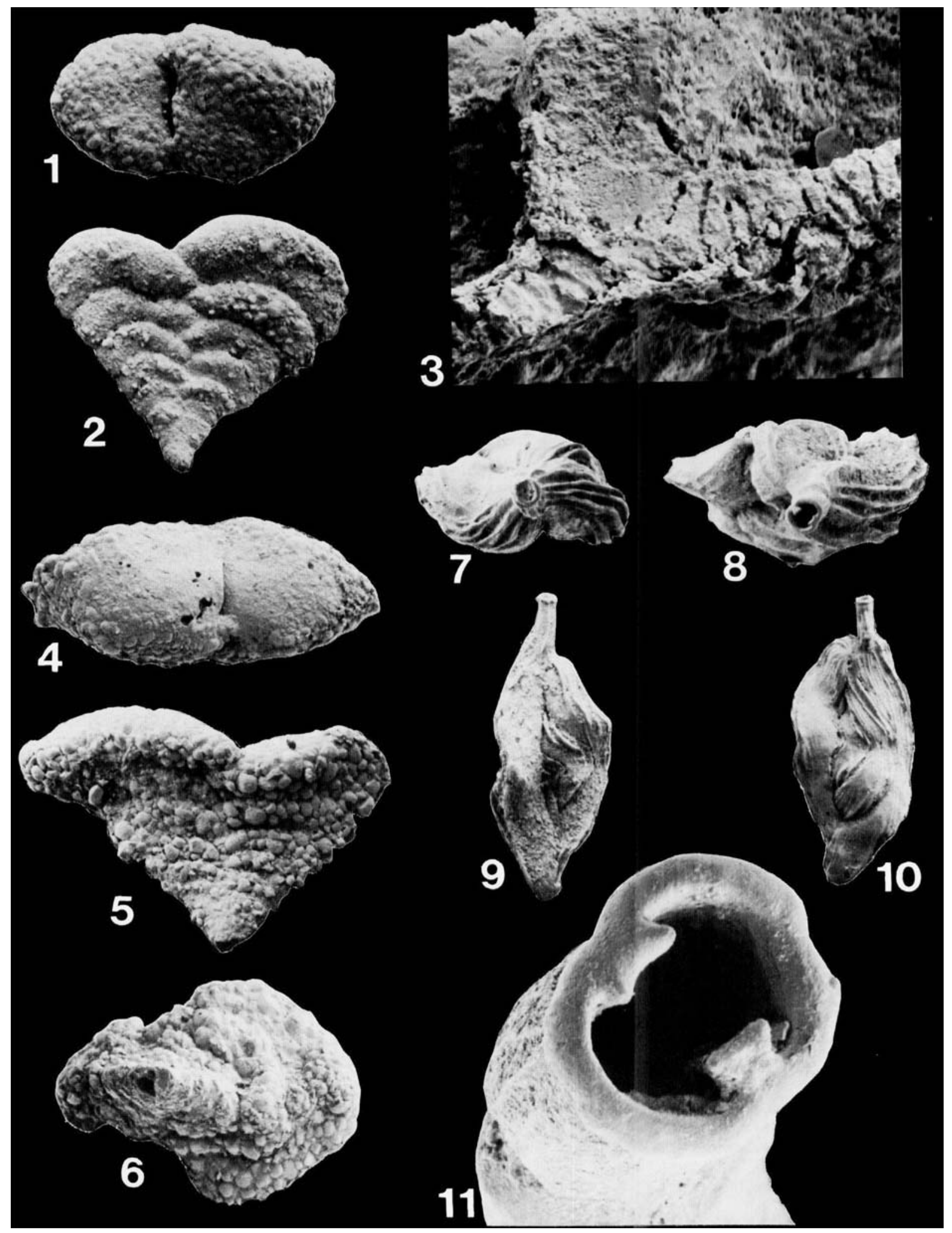


and branching parapores (sensu Hottinger et al., 1990). The aperture is a basal slit at the inner margin of the final chamber with a short flaplike lip bordered at its ends by apertural reentrants.

Dimensions. Maximum test height of the holotype $0.56 \mathrm{~mm}$. Occurrence. Sahulia lutzei is irregularly distributed in medium grained (biogenic) backreef samples in the lagoon of Madang, rare in the perireefal area. The species is lacking in muddy, organic rich sediments and in the low-salinity bay inlets where freshwater input is high.

Remarks. Resembles the specimen figured by Said (1949, Pl. 1, fig. 7) as Textularia conica d'Orbigny, but differs distinctly from the original drawings of Textularia conica by d'Orbigny (1839, Pl. 1, figs 19, 20) and the neotype selected by Le Calvez (1977, p. 18 , figs 1,2 ) in its more $V$-shaped outline and coarse agglutination and by the form of the apertural face. Interestingly the "short variety" of Textularia conica depicted by Brady (1884 Pl. 113, figs 1a-b) and collected off Hong Kong seems to represent a juvenile specimen belonging to the species described here. It differs, however, in its rather fine agglutination, the height of its chambers and in possessing a distinct rim bordering the entire apertural opening.

Suborder Miliolina Délage \& Hérouard, 1896

Superfamily Miliolacea Ehrenberg, 1839

Family Hauerinidae Schwager, 1876

Subfamily Hauerininae Schwager, 1876

Genus Cycloforina Luczkowska, 1972

Cycloforina collinsi sp. nov.

(Pl. 1, figs 7-11)

1922 Quinqueloculina cf. Q. collumnosa - Cushman, 65, Pl. 10, fig. 10.

1971 Quinqueloculina cf. Q. collumnosa Cushman - Bock, 18, Pl. 5, figs 9-11.

1988 Quinqueloculina cf. Q. collumnosa Cushman - Haig, 233, Pl. 5 , figs 11-14.

Derivation of name. This species is named in honour of Dr A.C. Collins (Geelong, Victoria) for his work on foraminifera at the Low Islands (Great Barrier Reef).

Diagnosis. A quinqueloculine, porcelaneous and imperforate species with numerous anastomosing costae, depressed sutures and a produced neck.

Holotype. Pl. 1, figs 10, 11. Reference UCMP No. 396735.

Paratypes. Pl. 1, figs 7-9. Reference UCMP No. 396736.

Material. The holotype and 6 paratypes.

Locality. The holotype is from sample No. L52, Lagoon of Madang, Wongat Island; $13.9 \mathrm{~m}$, Papua New Guinea. The paratypes are from sample No. L52, Lagoon of Madang, Wongat Island; $13.9 \mathrm{~m}$, Papua New. Guinea.

Description. Test free porcelaneous and imperforate, longer than broad, somewhat compressed with subacute periphery. Chambers distinct, arranged in a quinqueloculine pattern, polygonal in section; five chambers visible from the exterior. Sutures are depressed. Wall calcareous; shoulders and lateral parts of the test surface ornamented by numerous anastomosing costae which are parallel to oblique to the periphery of the chamber. Carinate edges of the chambers often becoming sinuous. Aperture produced on a short, slightly tapering neck, bordered by a circular rim and provided with two minute teeth with short bifid termination.

Dimensions. Maximum test height of the holotype $0.71 \mathrm{~mm}$. Occurrence. Cycloforina collinsi is common in medium grained (biogenic) backreef samples in the lagoon of Madang. The species is lacking in muddy, organic rich sediments and in the low-salinity bay inlets where freshwater input is high.

Remarks. Resembles strongly the specimens figured by Koutsoukos and Falcetta (1987, Pl., 1 figs 1-7) described under the name Adelosina pascuaensis from Easter Island in the southeastern Pacific. The species described herein differs from the latter in having a second, short bifid apertural tooth, more distinctive shoulders, is slightly more sinuate in apertural view and slimmer in side view.

\section{Genus Massilinoides McCulloch, 1977 Massilinoides baccaerti sp. nov.} (Pl. 2, figs 1-3)

Derivation of name. This species is named in honour of Dr. Jan Baccaert (University of Liége, Belgium) for his excellent work at the Lizard Island reef complex, Northern Great Barrier Reef.

Diagnosis. A porcelaneous, slightly flattened species with U-shaped chambers (in horizontal section), and characteristic, anastomosing microridges on the test surface.

Holotype. Pl. 2, figs 1, 3. Reference UCMP NO. 39677.

Paratype. Pl. 2, fig. 2. Reference UCMP No. 39678.

Material. The holotype and three paratypes.

Locality. The holotype is from sample No. L51, Lagoon of Madang, Wongat Island; $20.8 \mathrm{~m}$, Papua New Guinea. The paratypes are from sample No. L51, Lagoon of Madang, Wongat Island; $20.8 \mathrm{~m}$, Papua New Guinea.

Description. Test free, fusiform in outline, slightly flattened, periphery truncate. Chambers one half coil in length, $U$-shaped in horizontal section. Early chambers arranged in a quinqueloculine pattern, later in a single plane as in

\section{Explanation of Plate 2}

Figs 1-3. Massilinoides baccaerti sp. nov. (L51). Fig. 1, apertural view, (holotype) x90; Fig. 2, side view, (paratype) x40; Fig. 3, apertural view (note anastomosing microridges), (Holotype) $\times 33$.

Figs 4-6.Pseudolachlanella slitella gen. nov., sp. nov. (L52). Fig.4, side view, (holotype) x56; Fig. 5, side view, (paratype) x56; Fig. 6, enlarged portion of the apertural region, (paratype) $\times 200$.

Figs 7-8, Quinqueloculina debenayi sp. nov., (holotype, L37). Fig. 7, oblique peripheral view (note minute anastomosing microridges), (holotype) x80; Fig. 8, side view, (holotype) $x 80$.

Figs 9-10.Quinqueloculina stellicarinata sp. nov., (holotype, L37). Fig. 9, side view, (holotype) x110; Fig. 10, apertural view, (holotype) x130.

Figs 11-14.Pitella haigi gen. nov., sp. nov. (L52). Fig. 11, apertural view, (holotype) x120; Fig. 12, oblique side view, (paratype) x80; Fig. 13, side view, (holotype) x80; Fig. 14, enlargement of the pitted shell surface, (holotype) x800. 


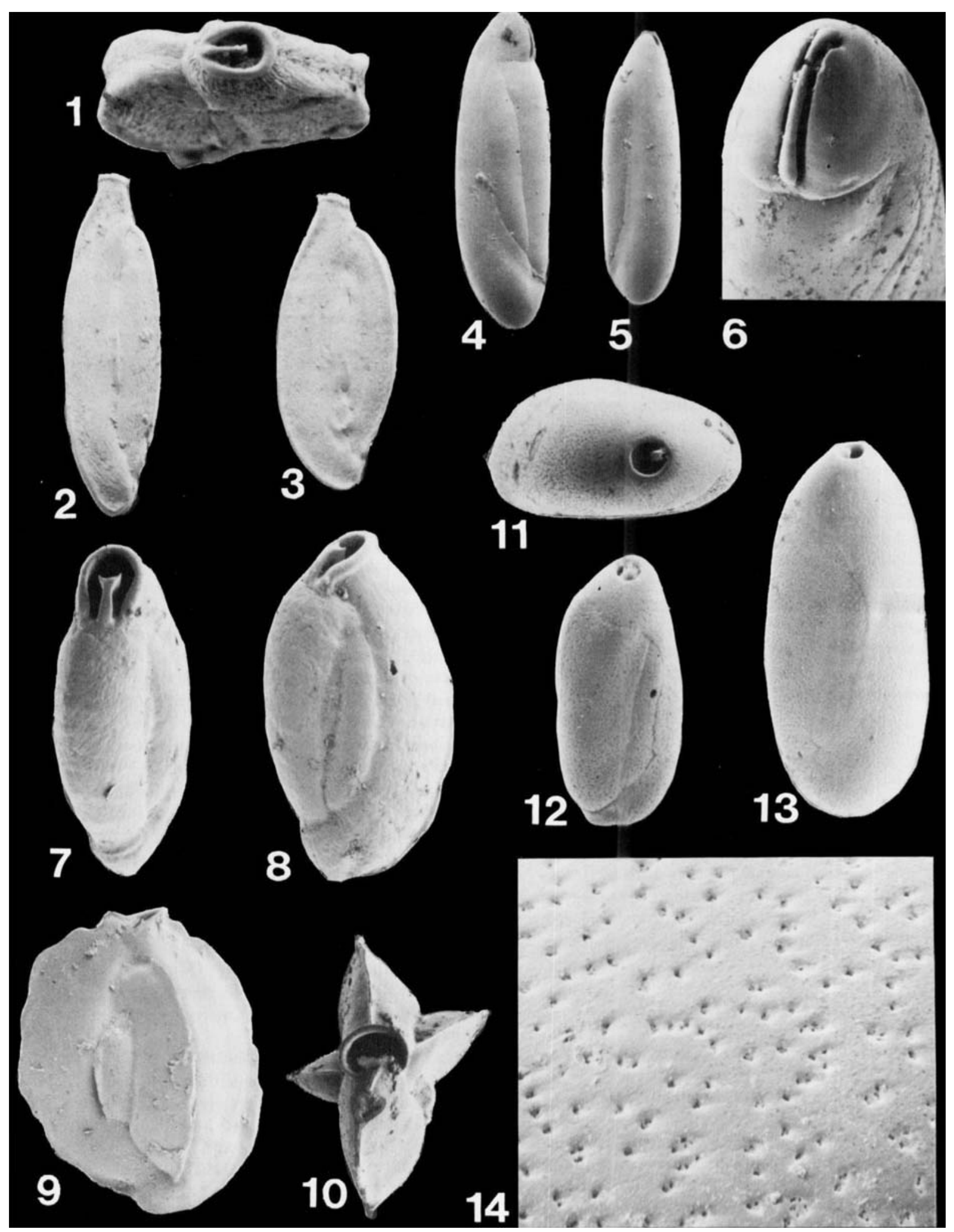


Spiroloculina. Wall calcareous, porcelaneous, imperforate. Surface with minute anastomosing microridges. Aperture ovate, produced on a short neck, bordered by a thickened rim and provided with a long, simple tooth with slightly thickened termination.

Dimensions. Maximum test height of the holotype $1.25 \mathrm{~mm}$. Occurrence. Massilinoides baccaerti is rare in medium grained (biogenic) backreef samples in the lagoon of Madang. The species is lacking in muddy, organic rich sediments and in the low-salinity bay inlets where freshwater input is high.

\section{Genus Quinqueloculina d'Orbigny, 1826 Quinqueloculina debenayi sp. nov.}

(Pl. 2, figs 7-8)

pars 1959 Quinqueloculina laevigata d'Orbigny - Graham \& Militante, 45, Pl. 5, figs 13a-c (not figs 12a-c).

Derivation of name. This species is named after Jean-Pierre Debenay (University of Angers) for his extensive studies on foraminifera in New Caledonia.

Diagnosis. A quinqueloculine, porcelaneous species of Quinqueloculina with slightly inflated chambers, depressed sutures and a test surface characterized by minute, anastomosing microridges.

Holotype. Pl. 2, figs 7-8. Reference UCMP No. 39679.

Paratype. Refrence UCMP No. 39680.

Material. The holotype and one paratype.

Locality. The holotype is from sample No. L48, Lagoon of Madang, $\mathrm{N}$ of Kranket Island; $17.4 \mathrm{~m}$, Papua New Guinea. The paratype is from sample No. L87, Lagoon of Madang, N-W of Rasch Pass; $15.0 \mathrm{~m}$, Papua New Guinea.

Description. Test free, porcelaneous and imperforate, fusiform in side view, laterally compressed. Chambers one-half coil in length, slightly inflated, arranged in a quinqueloculine pattern. Five chambers visible from the exterior. Sutures slightly depressed. Chamber margins subrounded in early stages, later tending to become carinated. Surface with minute anastomosing microridges. Aperture terminal, subcircular, bordered by a thickened collar-like peristomal rim and provided with a tooth with short bifid termination.

Dimensions. Maximum test height of the holotype $0.61 \mathrm{~mm}$. Occurrence. Quinqueloculina debenayi is very rare in fine to medium grained, (biogenic) backreef sediments in the lagoon of Madang. The species is lacking in muddy, organic rich sediments and in the low-salinity bay inlets where freshwater input is high.

\section{Quinqueloculina stellicarinata sp. nov.}

(P1. 2, figs 9-10)

Non 1958 Quinqueloculina crassicarinata -Collins, 359, Pl. 2, figs 6a-c.

Non 1988 Quinqueloculina crassicarinata Collins - Haig, 233, Pl. 5 , figs $18-20$.

Derivation of name. The name stellicarinata from lat. stella (star) and carina (keel)) refers to the star-shaped outline in apertural view and its keeled chamber margins.

Diagnosis. A small, porcelaneous species of Quinqueloculina with stellate and carinate chambers, and a rounded aperture with an anvil-shaped tooth.

Holotype. PI. 2, figs 9-10. Reference UCMP No. 39681.
Paratype. Reference UCMP No. 39682.

Material. The holotype and one paratype.

Locality. The holotype from sample No. L61, Lagoon of Madang, Malamal Anchorage; $41.7 \mathrm{~m}$, Papua New Guinea.

Description. Test small, porcelaneous, imperforate, subrectangular in lateral view, and star-like in apertural view. Chambers one-half coil in length, arranged in a quinqueloculine pattern so that finally five chambers are visible from the exterior. Chamber margins carinate; sutures slightly depressed. Surface covered with minute microridges. Aperture terminal, subcircular, bordered by a peristomal rim and provided with a broad, anvil-shaped, bifid tooth.

Dimensions. Quinqueloculina stellicarinata is very rare in medium grained, (biogenic) backreef samples in the lagoon of Madang. The species is lacking in muddy, organic rich sediments and in the low-salinity bay inlets where freshwater input is high.

Remarks. Differs from Cycloforina crassicarinata (Collins) in lacking the produced neck.

Family Hauerinidae Schwager, 1876

Subfamily Miliolinellinae Vella, 1957

Genus Pseudolachlanella gen. nov.

Description. Test free, elongate multilocular; chambers one half coil in length, early stage cryptoquinqueloculine (sensu Bogdanovich, 1969), later with planes of coiling increasing to almost $180^{\circ}$ to become nearly planispiral; chambers without a floor, broadly overlapping so that only three chambers are visible from the exterior; wall calcareous, imperforate, porcelaneous; surface smooth, aperture a very narrow, curved, elongate slit with parallel sides, provided with a long slender tooth with short, thickened termination.

Type species. Pseudolachlanella slitella gen. nov., sp. nov.

Remarks. The apertural features of this species do not correspond to those of any published genus. The new genus Pseudolachlanella differs from Lachlanella Vella, 1957 in its coiling mode, in its narrow and rather slitlike apertural opening and in lacking the everted apertural rim. It differs also from Triloculinella Riccio, 1950 in having a slitlike aperture with a long, slender, curved tooth, rather than an arch-like aperture covered by a broad apertural flap.

\section{Pseudolachlanella slitella gen. nov., sp. nov.} (Pl. 2, figs 4-6)

pars 1987 Quinqueloculina oblonga (Montagu) forma eburnea (d'Orbigny) - Baccaert, 98, Pl. 46, figs 4-5 (non fig. 3).

pars 1988 Quinqueloculina cf. Q. incisura (Todd) - Haig, 223, Pl. 6, figs $11,12,14$ (non fig. 13).

Derivation of name. Pseudolachlanella slitella because of the superficial resemblance to the slitlike aperture in Lachlanella. Diagnosis. A small, porcelaneous, species of Pseudolachlanella with a smooth test surface and a slitlike, curved aperture provided with a long slender tooth.

Holotype. Pl. 2, fig. 4. Reference UCMP No.. 39682.

Paratype. Pl. 2, figs 5-6. Reference UCMP No. 39683

Material. The holotype and two paratypes.

Locality. The holotype and the paratypes are from sample No. L52, Lagoon of Madang, Wongat Island; $13.9 \mathrm{~m}$, Papua New Guinea. 
Description. Test elongate, periphery subrounded, ovate in horizontal section. Chambers one half coil in length, early stage cryptoquinqueloculine later with planes of coiling increased to almost $180^{\circ}$ to become nearly planispiral. Chambers without a floor, broadly overlapping so that only three chambers are visible from the exterior. Wall calcareous, porcelaneous, surfacesmooth. Aperture a very narrow, curved, elongate slit with parallel sides, provided with a long slender tooth with short, thickened termination.

Dimensions. Maximum test height of the holotype $0.56 \mathrm{~mm}$. Occurrence. Pseudolachlanella slitella appears very seldom in medium grained, (biogenic) backreef sediments in the lagoon at Madang. The species is absent in muddy, organic rich sediments and in the low-salinity bay inlets where freshwater input is high.

\section{Family Miliolidae Ehrenberg, 1839 Subfamily Miliolinae Ehenberg, 1839 Genus Pitella gen nov.}

Description. Test free, elongate, multilocular; chambers one half coil in length, arranged in a cryptoquinqueloculine pattern (sensu Bogdanovich, 1969) and slightly inflated. The final three to four chambers visible from the exterior; wall calcareous, porcelaneous; surface pitted by pseudopores (sensu Hottinger et al., 1992); sutures very slightly depressed; aperture circular, bordered by a weakly developed, nonpitted, apertural rim and provided with a short, simple tooth with thickened termination.

Type species. Pitella haigi gen. nov. sp. nov.

Remarks. The pitted surface and the apertural features place this genus in the subfamily Miliolinae Ehrenberg, despite the fact that this subfamily is defined by a terminal aperture with a trematophore. Interestingly Loeblich \& Tappan (1987) included in the Miliolinae the genus Rupertianella with its terminal aperture bordered by arched lips.

Pitella differs from Triloculinella Riccio, 1950 in having a short, simple tooth and a pitted shell surface rather than an arch-like opening covered by a broad apertural flap. The new genus Pitella differs also from Rupertianella Loeblich \& Tappan, 1985 in having a rounded aperture provided with a short tooth rather than a simple narrow and elongate slit bordered by slightly arched lips.

Porcelaneous foraminifera with a pitted test surface belonging to the family Miliolidae Ehrenberg are known since the Eocene. The function of the pseudopores is unknown and needs further investigation.

Pitella haigi gen. nov., sp. nov.

(Pl. 2, figs 11-14)

non 1932 Quinqueloculina semireticulosa - Cushman, 27, Pl. 7, fig. 2.

1988 Quinqueloculina cf. Q. semireticulosa (Cushman) - Haig, 234, Pl. 8, figs 6-9.

Derivation of name. The new species Pitella haigi is named after David W. Haig (University of Western Australia, Nedlands) for his extensive work on miliolids from the Motupore Island, New Guinea. The generic name Pitella refers to the characteristic pitted test surface (pseudopores, sensu Hottinger et al., 1992).
Diagnosis. A small, porcelaneous species with pitted test surface (pseudopores) and rounded aperture.

Holotype. Pl. 2, figs 11, 13-14. Reference UCMP No. 39684.

Paratype. Pl. 2, fig. 12. Reference UCMP No. 39685.

Material. The holotype and four paratypes.

Locality. The holotype and the paratypes are from sample No. L52, Lagoon of Madang, Wongat Island; $13.9 \mathrm{~m}$, Papua New Guinea.

Description. Test small, elongate, ovate in horizontal section, periphery subrounded. Chambers one half coil in length, arranged in a cryptoquinqueloculine pattern. Chambers slightly inflated. The final three to four chambers visible from the exterior. Wall calcareous, porcelaneous; surface pitted by numerous pseudopores (sensu Hottinger et al., 1992). Sutures very slightly depressed. Aperture rounded, bordered by a weakly developed, nonpitted, apertural rim and provided with a short, simple tooth with thickened termination.

Dimensions. Maximum test height of the holotype $0.64 \mathrm{~mm}$. Occurrence. Rare, irregularly distributed in thelagoon. Occurs in patchreef, forereef and lagoonal samples between 10 and $50 \mathrm{~m}$.

\section{ECOLOGY}

All species described above are rare in sediment samples from shallow water $(0-55 \mathrm{~m})$ fore- and back-reef environments at Madang (0-55m). In the lagoon they are patchily distributed in fine and medium grained, biogenic sand and coarse, coral rubble. In thanatocoenoses their distribution matches the distribution of most of the larger symbiont bearing foraminifera (Assilina spp., Heterostegina depressa, Alveolinella quoyi, Sorites spp., Amphisorus hemprichii, Marginopora vertebralis). However, due to the lack of symbionts in the protoplasm of the new species, their depth and microhabitat requirements are less specific. Furthermore their morphology suggests also different microhabitat preferences (predominantly epifaunal and infaunal, compare Lipps, 1975, Langer, 1988, 1989, Kitazato, $1981,1988)$. In the well oxygenated, unconsolidated, coarse coral rubble they probably live sheltered within the pore space. An epifaunal way of life, however, is more probable on fine biogenic sand. They are absent in all bay inlets where fresh water influence is high and the muddy sediments contain a high amount of organic material of terrestrial origin.

\section{ACKNOWLEDGEMENTS}

I would like to thank Jere Lipps (Berkeley), Ze'ev Reiss (Jerusalem) and an anonymous reviewer for their helpful comments on the manuscript. Competent technical support was provided by $R$. Guggenheim and $M$. Düggelin (SEM-laboratories Basel, Switzerland). Collection of the material by J.H. Lipps was supported by NSF grant EAR 84-08001 and a Cristiansen Research Institute Fellowship. This study was supported by the Swiss Science Foundation, grant-Nr. 8220-028385 and is gratefully acknowledged.

Manuscript received September 1991

Revised manuscript accepted February 1992 


\section{REFERENCES}

Baccaert, J. 1987. Distribution Patterns and Taxonomy of Benthic Foraminifera in the Lizard island reef complex, Northern Great Barrier Reef, Australia. Unpubl. Ph.D. thesis, University of Liége.

Bender, H. 1989. Gehäuseaufbau, Gehäusegenese und Biologie agglutinierter Foraminiferen (Sarcodina, Textulariina). Jahrb. Geol. Bundesanstalt. 132 (2), 259-347, Pls. 1-17.

Bock, W.D. 1971. A handbook of the benthonic foraminifera of Florida Bay and adjacent waters. In: Jones, J.I. \& Bock, W.D. (Eds), A Symposium of Recent south Florida Foraminifera. Miami Geol. Soc. Mem. 1, 1-72.

Bogdanovich, A.K. 1969. To the revision of Miliolidae with quinqueloculine and triloculine structure of tests. Rocznik Polskiego Towarzystawa Geologicznego. 39, 351-360.

Brady, H.B. 1884. Report on the Foraminifera dredged by H.M.S. Challenger, during the years 1873-1876. Rep. scient. Results Voy. Challenger, Zoology, 9, 1-814, Pls 1-115.

Cimerman, F. \& Langer, M.R. 1991. Mediterranean Foraminifera Dela, Opera 30, Classis IV: Historia Naturalis, p. 1-119, Pls 1-93, Ljubljana.

Collins, A.C. 1958. Foraminifera. British Museum (Natural History), Great Barrier Reef Expedition 1928-1929, Sci. Rep., 6 (6), 335-437, Pls 1-5.

Cushman, J.A. 1921: Foraminifera of the Philippine and adjacent seas. U.S. Nat. Mus. Bull., Washington, 100 (4), 608pp., Pls 1-100.

Cushman, J.A. 1922. Shallow water foraminifera of the Tortugas Region. Publ. Carnegie Inst. Washington, No.311, Dept. Mar. Biol., 17, 1-85, Pls 1-14.

Cushman, J.A. 1932. The Foraminifera of the tropical Pacific collections of the "Albatross", 1899-1900; Part 1. Astrorhizidae to Trochamminidae. U.S. Nat Mus. Bull. Washington, 161, 1-88, Pls 1-17.

Cushman, J.A. 1933. The Foraminifera of the tropical Pacific collections of the "Albatross", 1899-1900; Part 2. Lagenidae to Alveolinellidae. U.S. Nat. Mus. Bull., Washington, 161, 1-79, Pls 1-19.

Cushman, J.A. 1942. The Foraminifera of the tropical Pacific collections of the "Albatross", 1899-1900; Part 3. Heterohelicidae and Buliminidae. U.S. Nat. Mus. Bull., Washington, 161, 1-67, Pls 1-15.

Debenay, J.-P. 1986. Le lagon sud-ouest et la marge insulaire sud de Bouvelle-Calédonie: Importance et répartition des Foraminiféres de grande taille, leur importance dans la sédimentogénese. Cah. d'Ocean trop., 20, 171-179.

Debenay, J.-P. 1988. Foraminifera larger than $0.5 \mathrm{~mm}$ in the southwestern lagoon of New Caledonia: Distribution related to abiotic properties. J. Foram. Res. 18 (2), 258-175.

d'Orbigny, A.D. 1839. Foraminiféres. In: Ramone de la Sagra: Histoire physique, politique et naturelle de l'ile de Cuba. 1-224, Pls 1-12, Paris: A. Bertrand.

Graham, J.J. \& Militante, P.J. 1959. Recent Foraminifera from the Puerto Galera area, northern Mindoro, Philippines. Stanford University Publ., Geol. Sciences, 6, 1-171, PIs 1-19.

Haig, D.W. 1988. Miliolid foraminifera from inner neritic sand and mud facies of the Papuan Lagoon, New Guinea. J. Foram. Res., 18 (3), 203-236, Pls 1-11.

Haynes, J.R. 1990. The classification of the foraminifera - A review of historical and philosophical perspectives. Paleontology, 33 (3), 503-528.

Heron-Allen, E. \& Earland, A. 1915. The foraminifera of the Kerimba Archipelago (Portugese East Africa). Trans. Zool. Soc. London, Pt II, 20 (17), 543-794.

Hofker, J. 1927. The foraminifera of the Siboga Expedition; families Tinoporidae, Rotaliidae, Nummulitidae, Amphisteginidae; Part 1. Siboga-Expeditie, Mon. IV, 1-78, Pls 1-38. E.J. Brill, Leiden.

Hofker, J. 1930. The foraminifera of the Siboga Expedition; families Astrorhizidae, Rhizamminidae, Reophacidae, Anomalinidae,
Peneroplidae; Part 2. Siboga-Expeditie, Mon. IVa, 79-170, Pls 1-64. E.J. Brill, Leiden.

Hofker, J. 1933. Foraminifera of the Malay Archipelago. Vidensk. Medd. Dansk Naturh. Foren., Kobenhaven, 93, 71-167.

Hofker, J. 1951. The foraminifera of the Siboga Expedition, Part III. Siboga-Expeditie, Mon. IVa, 1-513. E.J. Brill, Leiden.

Hofker, J. 1968. Foraminifera from the Bay of Jakarta, Java. Bijdragen Tot de Dierkunde, Amsterdam, 37, 11-59, Pls 1-12.

Hottinger, L. 1983. Processes determining the distribution of larger foraminifera in space and time. Utrecht Micropal. Bull., 30, 239-253.

Hottinger, L., Halicz, E. \& Reiss, Z. 1990. Partitions and fistulose chamberlets in Textulariina. In: Hemleben C., Kaminski, M.A., Kuhnt, W. \& Scott, D.B. (Eds), Paleoecology, Biostratigraphy, Paleoceanography and Taxonomy of Agglutinated Foraminifera. NATO ASI Series C: Math. Phys. Sci., 327, 37-49, Pls 1-5. Kluwer Acad. Publ., Dordrecht.

Hottinger, L., Halicz, E. \& Reiss, Z. 1990a. Wall texture of Spirorutilus. J. Foram. Res., 20 (1), 65-70.

Hottinger, L. \& Pecheux, J.-F. (in press). Report on the foraminifera of the photic zone in South-Western Mauritius. Fazies, Erlangen.

Hottinger, L., Halicz, E. \& Reiss, Z. 1992 (in press). Recent Foraminiferida from the Gulf of Aqaba (Red Sea). Schweiz. Palaont. Abh., Basel.

Kitazato, H. 1981. Observations and behaviour and mode of life of benthic foraminifers in the laboratory. Geosci. Rep. Shizuoka Univ., 6, 61-71.

Kitazato, H. 1988. Locomotion of some benthic Foraminifera in and on sediments. I. Foram. Res., 18 (4), 344-349.

Koutsoukos, E.A.M. \& Falcetta, M.M. 1987. Adelosina pascuaensis, n. sp.; A new species of miliolid (Foraminiferida) from the shore sediments of Easter Island (Isla de Pascua), Chile, Southeastern Pacific. Rev. Paléobiol., 6 (1), 151-154.

Langer, M.R. 1988. Recent epiphytic Foraminifera from Vulcano (Mediterranean Sea). Rev. Paléobiol. Vol. Spec. No. 2, BENTHOS'86, 827-832, Genéve.

Langer, M.R. 1989. Distribution, diversity and functional morphology of benthic foraminifera from Vulcano (Mediterranean Sea). Unpubl. Ph.D. thesis, 1-115, Pls 1-31. University of Basel.

Le Calvez, Y. 1977. Révision des foraminiféres de la collection d'Orbigny. II - Foraminiféres de l'ile de Cuba. Cah. Micropal., Tome 1, 1-128.

Lipps, J.H. 1975. Feeding strategies and test function in foraminifera. Proc. "Benthonics 1975" p.26, Dalhousie Univ., Halifax.

Loeblich, A.R. \& Tappan, H. 1987. Foraminiferal genera and their classification. Van Nostrand Reinhold Co., New York, 2 vols, x+970pp.; viii+212pp., 847 Pls.

Margerel, J.-P. 1981. Espéces nouvelles de Foraminiféres de la baie de St. Vincent (Nouvelle-Calédonie): Cah. Micropal., 4, 67-72.

Millett, F.W. 1898a. Report on the Recent Foraminifera of the Malay Archipelago collected by Mr A. Durrand, F.R.M.S.; Part 2. J. Roy. Microscop. Soc., 258-269, Pls 5-6.

Millett, F.W. 1898b. Report on the Recent Foraminifera of the Malay Archipelago collected by Mr A. Durrand, F.R.M.S.; Part 2. J. Roy. Microscop. Soc., 499-513, Pls 11-12.

Millett, F.W. 1898c. Report on the Recent Foraminifera of the Malay Archipelago collected by Mr A. Durrand, F.R.M.S.; Part 3. J. Roy. Microscop. Soc., 607-614, Pls 13.

Rasheed, D.A. 1971. Some foraminifera belonging to Miliolidae and Ophtalmidiidae from the Coral Sea, south of Papua (New Guinea) Part 2. The Madras Univers. 1., 37/38, 19-68.

Reiss, Z. \& Hottinger, L. 1984. The Gulf of Aqaba - Ecological Micropaleontology. Ecological Studies 50, Springer Verlag, Berlin, Heidelberg, 354pp.

Said, R. 1949. Foraminifera of the Northern Red Sea. Cush. Lab. Foram. Res., Spec. Publ., 26, 1-44, Pls 1-4. 
APPENDIX

Location of samples (see Fig. 1)

\begin{tabular}{lllll}
$\begin{array}{l}\text { Sample } \\
\text { No. }\end{array}$ & Locality & Latitude/Longitude & $\begin{array}{c}\text { Depth } \\
\text { in } \mathbf{~}\end{array}$ \\
L22 & N of Rasch Pass & $5^{\circ} 09.1^{\prime} \mathrm{S} / 145^{\circ} 49.4^{\prime} \mathrm{E}$ & 24.3 & \multicolumn{1}{c}{ Substrate } \\
L23 & N of Rasch Pass & $5^{\circ} 09.2^{\prime} \mathrm{S} / 145^{\circ} 49.4^{\prime} \mathrm{E}$ & 20.8 & Sand, coral rubble Halimeda \\
L25 & N of Rasch Pass & $5^{\circ} 09.9^{\prime} \mathrm{S} / 145^{\circ} 49.2^{\prime} \mathrm{E}$ & 14.0 & sand, coarse coral rubble \\
L34 & SW of Wongat Island & $5^{\circ} 08.8^{\prime} \mathrm{S} / 145^{\circ} 49.3^{\prime} \mathrm{E}$ & 24.3 & coral rubble, Halimeda \\
L37 & SEK Harbour & $5^{\circ} 05.2^{\prime} \mathrm{S} / 145^{\circ} 48.9^{\prime} \mathrm{E}$ & 52.1 & biogenic detrital sand, coral rubble \\
L48 & N of Kranket Island & $5^{\circ} 11.4^{\prime} \mathrm{S} / 145^{\circ} 49.9^{\prime} \mathrm{E}$ & 17.4 & dark organic mud, scaphopods \\
L51 & Wongat Island & $5^{\circ} 08.3^{\prime} \mathrm{S} / 145^{\circ} 49.6^{\prime} \mathrm{E}$ & 20.8 & fine detrital sand, coral rubble \\
L52 & Wongat Island & $5^{\circ} 08.4^{\prime} \mathrm{S} / 145^{\circ} 49.6^{\prime} \mathrm{E}$ & 13.9 & detrital sand, mud, Halimeda \\
L61 & Malamal Anchorage & $5^{\circ} 05.7^{\prime} \mathrm{S} / 145^{\circ} 49.1^{\prime} \mathrm{E}$ & 41.7 & detrital sand \\
L87 & N-W of Rasch Pass & $5^{\circ} 09.7^{\prime} \mathrm{S} / 145^{\circ} 49.5^{\prime} \mathrm{E}$ & 15.0 & detrital sand
\end{tabular}

